\title{
No association of G72 and D-amino acid oxidase genes with schizophrenia
}

\author{
Yu-Li Liu ${ }^{\mathrm{a}}$, Cathy Shen-Jang Fann ${ }^{\mathrm{b}}$, Chih-Min Liu ${ }^{\mathrm{c}}$, Chien Ching Chang ${ }^{\mathrm{b}}$, \\ Jer-Yuarn Wu ${ }^{\mathrm{d}}$, Shuen-Iu Hung ${ }^{\mathrm{d}}$, Shih-Kai Liu ${ }^{\mathrm{c}}$, Ming H. Hsieh ${ }^{\mathrm{c}}$, \\ Tzung-Jeng Hwang ${ }^{c}$, Hung-Yu Chan ${ }^{\mathrm{e}}$, Jiahn-Jyh Chen ${ }^{\mathrm{e}}$, Stephen V. Faraone ${ }^{\mathrm{f}}$, \\ Ming T. Tsuang ${ }^{g, h, i}$, Wei J. Chen ${ }^{j}$, Hai-Gwo Hwu ${ }^{c, j, k, *}$ \\ ${ }^{a}$ Division of Mental Health and Substance Abuse Research, National Health Research Institutes, Taipei, Taiwan \\ ${ }^{\mathrm{b}}$ Institute of Biomedical Sciences, Academia Sinica, Taipei, Taiwan \\ c Department of Psychiatry, National Taiwan University Hospital and National Taiwan University College of Medicine, Taipei, Taiwan \\ ${ }^{\mathrm{d}}$ National Genotyping Center, Institute of Biomedical Sciences, Academia Sinica, Taipei, Taiwan \\ e Taoyuan Psychiatric Center, Taoyuan, Taiwan \\ ${ }^{\mathrm{f}}$ Medical Genetics Research Center, Departments of Psychiatry and Neuroscience and Physiology, SUNY Upstate Medical University, USA \\ ${ }^{\mathrm{g}}$ Harvard Institute of Psychiatric Epidemiology and Genetics, Harvard Departments of Epidemiology and Psychiatry, Boston, MA, USA \\ ${ }^{\mathrm{h}}$ Institute of Behavioral Genomics, Department of Psychiatry, University of California, San Diego, USA \\ ${ }^{\text {i }}$ San Diego VA Healthcare System, USA \\ ${ }^{\mathrm{j}}$ Institute of Epidemiology, College of Public Health, National Taiwan University, Taipei, Taiwan \\ ${ }^{\mathrm{k}}$ Department of Psychology, College of Science, National Taiwan University, Taipei, Taiwan
}

Received 16 August 2005; received in revised form 12 June 2006; accepted 12 June 2006

Available online 13 July 2006

\begin{abstract}
The genes of D-amino acid oxidase (DAAO) activator (DAOA or G72; 13q34) and DAAO (12q24) have been suggested as candidate genes and involved in the $N$-methyl-D-aspartate receptor regulation pathway for schizophrenia. In order to evaluate the potential association of these two genes with schizophrenia in a Taiwanese sample, three single nucleotide polymorphisms (SNPs) for DAAO (rs2111902, rs3918346, rs3741775) and eleven SNPs for G72 (rs3916965, rs3916966, rs3916967, rs2391191, rs3916968, rs947267, rs778294, rs3916970, rs3916971, rs778293, rs3918342) were genotyped by the MALDI-TOF mass spectrometry method in 218 families (864 individuals) containing at least two siblings affected with schizophrenia. In SNP-based single locus association analyses, neither G72 nor DAAO showed significant association with schizophrenia. Additionally, a threeSNP haplotype in DAAO, and a four-SNP as well as a two-SNP haplotype in G72, showed no significant associations with schizophrenia. These results suggest that the DAAO and G72 genes are not susceptibility genes for schizophrenia in a Taiwanese sample.
\end{abstract}

(C) 2006 Elsevier B.V. All rights reserved.

Keywords: DAAO; G72; Schizophrenia; Taiwanese family; SNP; Haplotype

\footnotetext{
* Corresponding author. Department of Psychiatry, National Taiwan University Hospital, No. 7, Chung San South Road, Taipei 100, Taiwan, ROC. Tel.: +8862 2312 3456x6657; fax: +88622331 4775 .

E-mail address: haigohwu@ha.mc.ntu.edu.tw (H.-G. Hwu).
} 


\section{Introduction}

D-Amino acid oxidase (DAAO) is a flavoenzyme of peroxisomes presented in the brain, kidney and liver of mammals (Fukui and Miyake, 1992). DAAO may regulate the $N$-methyl-D-asparate (NMDA) receptor by oxidizing its agonist D-serine amino acid in the brain (Detera-Wadleigh and McMahon, in press; Goldberg et al., in press). The DAAO gene is composed of 11 exons distributed in $25 \mathrm{~kb}$ at chromosome 12q24.11. The research interest in D-amino acid oxidase (DAAO) and its activator G72 (or DAOA) as susceptibility genes for schizophrenia was initiated by several reports of linkage of G72 at the chromosome 13q22-q34 region (Blouin et al., 1998; Brzustowicz et al., 1999; Riley et al., 1998; Shaw et al., 2003). In spite of several subsequent negative linkage study results (DeLisi et al., 2000, 2002; Fallin et al., 2003), the G72 locus was shown to be significantly associated with schizophrenia using single nucleotide polymorphism (SNP)-based fine mapping studies following the linkage study in a French Canadian and a Russian sample (Chumakov et al., 2002). The G72 mRNA showed higher levels of expression in the dorsolateral prefrontal cortex (DLPFC) in schizophrenic patients (Korostishevsky et al., 2004). The search for schizophrenia susceptibility genes related to G72 was continued by a yeast twohybrid experiment, which identified that the enzyme DAAO may interact with G72 on the protein level (Chumakov et al., 2002). The role of DAAO as a susceptibility gene was further confirmed by the finding of association of four intronic SNPs (MDAAO-4, MDAAO-5, MDAAO-6, and MDAAO-7) proving its association with schizophrenia in French Canadian and Russian populations via univariate analysis (Chumakov et al., 2002).

These two susceptibility genes were later confirmed in Chinese (Liu et al., 2004; Wang et al., 2004), German (Schumacher et al., 2004), and Ashkenazi samples (Korostishevsky et al., 2004) using SNP fine mapping of case-control studies. This study was conducted to evaluate the association findings for these two genes with schizophrenia using 218 Taiwanese schizophrenia families with a minimum of two affected siblings.

\section{Method}

\subsection{Subjects}

This research project was approved by the Institutional Review Board of the National Taiwan University Hospital. After obtaining the signed documentation of informed consent, the study subjects were recruited for diagnostic assessment and collection of blood samples for extraction of genomic DNA. The subjects were recruited from two sample-collecting programs: the multidimensional psychopathology study of schizophrenia (MPSS) (Hwu et al., 2002), conducted from 1993 to 2001; and the Taiwan schizophrenia linkage study (TSLS) (Hwu et al., 2005), conducted from 1998 to 2002. The 86 families of the MPSS subjects were interviewed by the research psychiatrists using the Psychiatrist Diagnostic Assessment (PDA) (Hwu, 1999). The 132 families of the TSLS subjects were interviewed by well-trained assistants using the Mandarin Chinese version of the Diagnostic Interview for Genetic Studies (DIGS) (Chen, 1999). The final diagnostic assessment of both MPSS and TSLS subjects were formulated by integrating either the PDA or the DIGS data and clinical information from medical chart records using the Specialist Diagnostic Assessment Sheet (SDAS), based upon the criteria of the Diagnostic and Statistical Manual of Mental Disorders, 4th edition (DSM-IV). The study samples included 218 schizophrenic nuclear families with at least two affected siblings, which resulted in a total of 864 subjects being genotyped (Table 1). Within these 218 families, 216 families had at least two sibs genotyped, 103 had one parent, and 96 had both parents genotyped in this study.

\subsection{SNP genotyping}

All SNP markers of the DAAO gene and 2 SNP markers (M15 and M19) of the G72 gene were selected from a previously published report (Chumakov et al., 2002), and the other SNP markers of G72 were selected by intermarker distance, with an average distance of $7.5 \mathrm{~kb}$. All SNP markers were genotyped by matrixassisted laser desorption/ionization-times of flight mass spectrometry (MALDI-TOF MS). A DNA fragment (100-300 bp) encompassing the SNP site was amplified

Table 1

Distribution of families by the number of siblings and parents genotyped

\begin{tabular}{lcrrr}
\hline \multirow{2}{*}{$\begin{array}{l}\text { Sibs genotyped } \\
\text { per family }\end{array}$} & \multicolumn{4}{c}{ Parents genotyped per family } \\
\cline { 2 - 5 } & 0 & 1 & 2 & Total families \\
\hline 1 & 0 & 0 & 2 & 2 \\
2 & 9 & 15 & 74 & 98 \\
3 & 8 & 78 & 17 & 103 \\
4 & 2 & 9 & 2 & 13 \\
5 & 0 & 1 & 1 & 2 \\
Total families & 19 & 103 & 96 & 218 \\
\hline
\end{tabular}


by polymerase chain reaction (PCR), using a GeneAmp 9700 thermocycler (Applied Biosystems, USA) according to the manufacturer's instructions. After the PCR amplification and neutralization of the deoxynucleotide triphosphate (dNTP) were performed, the primer extension was done by adding the probe, Thermo Sequenase (Amersham Pharmacia, Piscataway, NJ, USA) and the appropriate dideoxynucleotide triphosphate (ddNTP)/ dNTP mixture. Extension products were differentiated by mass through the MALDI-TOF.

\subsection{Statistical analyses}

The quality of genotyping data were checked on indicators of Hardy-Weinberg equilibrium, lineage of study families, and deviation from Mendelian inheritance, using the ALLELE procedure in the SAS/ GENETICS (SAS-Institute, 2002), PEDCHECK (O'Connell and Weeks, 1998), and UNKNOWN (Hovatta et al., 1999), respectively. Haplotype blocks were defined using the linkage disequilibrium of intermarkers measured by coefficient $D^{\prime}$ (Lewontine, 1964), and demonstrated using a graphic presentation by GOLD software (Abecasis and Cookson, 2000). An individual's haplotype was inferred using SimWalk2 version 2.86 (Sobel and Lange, 1996), which is based on the Markov Chain Monte Carlo algorithm. The phenotype of schizophrenia was divided into narrow models (DSM-IV defined schizophrenia only) and broad models (including schizophrenia, schizoaffective, and other non-affective psychotic disorders defined by DSM-IV) for the association study.

Using an affected sibpair design, both linkage and family-based association analysis can be carried out; the former tests cosegregation of markers and the putative disease gene, and the latter tests whether it is more likely a specific allele/haplotype gets transmitted to affected offspring more often than expected. Multiple sibs in a sibship can be included in the family-based association, using techniques such as bootstrapping to avoid problems arising from dependence. In this study, we relied on association analysis due to its higher resolution and greater suitability for fine mapping disease genes. The single and multipoint association tests were carried out using TRANSMIT (Clayton, 1999) and FBAT (Horvath et al., 2004) programs. All affected siblings were included in the calculations because both of the programs were robust to inclusion of multiple affected offspring in each family.

\section{Results}

Three SNPs of DAAO and eleven SNPs of G72 were first validated in a small subsample of 92 biologically

Table 2

Minor allele frequencies of the single nucleotide polymorphisms of the DAAO and G72 genes and association with narrow and broad phenotype models of schizophrenia

\begin{tabular}{|c|c|c|c|c|c|c|c|c|c|}
\hline \multirow[t]{2}{*}{ Genes } & \multirow[t]{2}{*}{ SNP_ID } & \multirow[t]{2}{*}{ Chromosome } & \multirow{2}{*}{$\begin{array}{l}\text { Allele } \\
\text { type }\end{array}$} & \multirow[t]{2}{*}{$\mathrm{MF}^{\mathrm{a}}$} & \multirow{2}{*}{$\frac{\mathrm{HW} \text { test }^{\mathrm{b}}}{P^{\mathrm{e}}}$} & \multicolumn{2}{|c|}{ Narrow model ${ }^{\mathrm{c}}$} & \multicolumn{2}{|c|}{ Broad model $^{\mathrm{d}}$} \\
\hline & & & & & & $N^{\mathrm{f}}$ & $P^{\mathrm{e}}$ & $N^{\mathrm{f}}$ & $P^{\mathrm{e}}$ \\
\hline \multirow[t]{3}{*}{ DAAO } & MDAAO-4 (rs2111902) & chr12:109211693 & $\mathrm{G} / \mathrm{T}$ & 0.48 & 0.9248 & 216 & 0.5144 & 218 & 0.6831 \\
\hline & MDAAO-5 (rs3918346) & $\operatorname{chr12:109214830}$ & $\mathrm{A} / \mathrm{G}$ & 0.49 & 0.8961 & 215 & 0.8497 & 218 & 0.8592 \\
\hline & MDAAO-6 (rs3741775) & chr12:109216549 & $\mathrm{A} / \mathrm{C}$ & 0.40 & 0.9814 & 215 & 0.4000 & 217 & 0.5163 \\
\hline \multirow[t]{11}{*}{$\mathrm{G} 30 / \mathrm{G} 72$} & G30 (rs3916965) & chr13:104939998 & $\mathrm{T} / \mathrm{C}$ & 0.36 & 0.1826 & 216 & 0.4548 & 217 & 0.5200 \\
\hline & G72 (rs3916966) & chr13:104947533 & $\mathrm{C} / \mathrm{A}$ & 0.38 & 0.1388 & 216 & 0.5205 & 218 & 0.5583 \\
\hline & G72 (rs3916967) & chr13:104953986 & $\mathrm{C} / \mathrm{T}$ & 0.37 & 0.1362 & 214 & 0.3596 & 216 & 0.3661 \\
\hline & G72 (M15; rs2391191) & $\operatorname{chr13:104956084}$ & $\mathrm{A} / \mathrm{G}$ & 0.37 & 0.1362 & 214 & 0.3381 & 216 & 0.3702 \\
\hline & G72 (rs3916968) & chr13:104957057 & $\mathrm{C} / \mathrm{T}$ & 0.18 & 0.9268 & 215 & 0.2936 & 217 & 0.2213 \\
\hline & G72 (rs947267) & chr13:104998639 & $\mathrm{T} / \mathrm{G}$ & 0.38 & $0.0054^{g}$ & 213 & 0.7021 & 215 & 0.6918 \\
\hline & G72 (rs778294) & $\operatorname{chr13:104964167}$ & $\mathrm{C} / \mathrm{T}$ & 0.15 & 0.1182 & 216 & 0.9532 & 218 & 0.9853 \\
\hline & G30 (rs3916970) & chr13:104976300 & $\mathrm{T} / \mathrm{C}$ & 0.43 & 0.1366 & 216 & 0.3903 & 218 & 0.6335 \\
\hline & G30 (rs3916971) & chr13:104978873 & $\mathrm{T} / \mathrm{C}$ & 0.47 & 0.0608 & 215 & 0.2079 & 217 & 0.2260 \\
\hline & G30 (M19; rs778293) & chr13:105005837 & $\mathrm{T} / \mathrm{C}$ & 0.33 & 0.8671 & 216 & 0.0650 & 218 & 0.0603 \\
\hline & G30 (rs3918342) & chr13:105022387 & $\mathrm{T} / \mathrm{C}$ & 0.46 & $0.0399^{g}$ & 216 & 0.1181 & 218 & 0.1041 \\
\hline
\end{tabular}

\footnotetext{
${ }^{a}$ MF: minor allele frequency.

b HW: Hardy-Weinberg's test.

c Narrow model: only subjects of schizophrenia who meet the criteria of the Diagnostic and Statistical Manual IV (DSM-IV).

${ }^{\mathrm{d}}$ Broad model: composed of DSM-IV schizophrenia, schizoaffective disorder and non-affective psychotic disorders.

e $P$ : $P$-value.

${ }^{\mathrm{f}} N$ : number of families.

g Bold text: significant deviation $(P<0.05)$ from Hardy-Weinberg's equilibrium test.
} 
Table 3

Haplotype frequencies (HF) of DAAO gene and association with narrow and broad phenotype models of schizophrenia

\begin{tabular}{|c|c|c|c|}
\hline \multirow{2}{*}{$\begin{array}{l}\text { Haplotype } \\
\text { (MDAAO-4- } \\
\text { MDAAO-5- } \\
\text { MDAAO-6) } \\
\text { (intron 1-intron } \\
\text { 3-intron 4) }\end{array}$} & \multirow[t]{2}{*}{$\mathrm{HF}$} & $\begin{array}{l}\text { Narrow model } \\
(N=216)\end{array}$ & $\begin{array}{l}\text { Broad model } \\
(N=218)\end{array}$ \\
\hline & & $P$-value & $P$-value \\
\hline $\mathrm{G}-\mathrm{A}-\mathrm{A}$ & 0.521606 & 0.783157 & 0.963726 \\
\hline $\mathrm{T}-\mathrm{A}-\mathrm{A}$ & 0.002471 & 0.33252 & 0.334077 \\
\hline $\mathrm{G}-\mathrm{G}-\mathrm{A}$ & 0.004106 & 0.224668 & 0.224621 \\
\hline $\mathrm{T}-\mathrm{G}-\mathrm{A}$ & 0.081497 & 0.622399 & 0.599163 \\
\hline $\mathrm{G}-\mathrm{G}-\mathrm{C}$ & 0.012972 & 0.426568 & 0.423143 \\
\hline $\mathrm{T}-\mathrm{G}-\mathrm{C}$ & 0.377258 & 0.391929 & 0.540616 \\
\hline
\end{tabular}

$N$ : Number of families.

independent individuals to ensure the existence of the polymorphism in the Taiwanese ethnic group. A SNP was included in the analysis if the minor allele frequency was larger than $10 \%$ and the genotype missing rate was smaller than $30 \%$. All the SNP markers were compatible with the Hardy-Weinberg equilibrium distribution except rs947267 and rs3918342 of G72 (Table 2), which were excluded in the broader analysis. A haplotype block was formed if the intermarker LD coefficient $\left(D^{\prime}\right)$ was higher than 0.7 . For DAAO, one haplotype block with three SNP markers (MDAAO-4MDAAO-5-MDAAO-6) was formed. For G72, two haplotype blocks were formed; one with four SNP markers (rs3916965-rs3916966-rs3916967rs2391191) and the other with two SNP markers (rs947267-rs778294).

In single SNP locus association analyses using the TRANSMIT (Clayton, 1999) and FBAT (Horvath et al., 2004) programs, there were no significant associations found for G72 and DAAO in both the narrow and broad phenotype models of schizophrenia (Table 2). Haplotype analyses of the three-SNP (MDAAO-4-MDAAO5-MDAAO-6) haplotype of DAAO gene failed to identify significant associations in any compositions of the block (Table 3), and no significant associations in any compositions of either the two-SNP or four-SNP blocks of G72 were found either (Table 3-1).

\section{Discussion}

In this study, we evaluated the association of two candidate genes for schizophrenia, G72 (located on 13q33.2) and DAAO (located on 12q24.11), using single locus and haplotype-based, family-based association analyses. The selected SNPs on G72 were not fully consistent with the SNPs reported by Chumakov et al.
(2002), but were exactly the same SNPs reported by Korostishevsky et al. (2004). Both reports found significant associations between G72 and schizophrenia. However, our results on G72 did not replicate the strong significant associations reported by these two groups. None of the single locus or the haplotype association analyses were significant at this region. We conclude that the association of G72 with schizophrenia is negative in our Taiwanese sample.

The SNPs for DAAO were selected from those significantly associated with schizophrenia, as reported by Chumakov et al. (2002). These three SNPs (MDAAO-4 in intron 1, MDAAO-5 in intron 3 and MDAAO-6 in intron 4) did not show a significant association in our single locus association analyses, in contrast with the results reported from a German (Schumacher et al., 2004) and a Chinese (Liu et al., 2004) sample. In the German sample, there were significant associations with all three SNPs; in the Chinese sample, the significant association was found at SNP MDAAO-6 (Liu et al., 2004). Given that our study was the only one using a family-based association design, and all the others used the case-control design, it is possible that the case-control study is more sensitive with regard to single SNP allele-type association analysis (Zhang et al., 2002). It is also possible that the stratification artifacts have given false positive results in the case-control studies or that these results are due to the differential effects of genotyping errors found in family-based and case-control studies (Mitchell et al., 2003).

In this study, we found no haplotypes which increased risk for schizophrenia, in contrast with the

Table 3-1

Haplotype frequencies (HF) of G72 gene and association with narrow and broad phenotype models of schizophrenia

\begin{tabular}{|c|c|c|c|c|}
\hline \multirow[t]{2}{*}{ Haplotypes } & & \multirow[t]{2}{*}{$\mathrm{HF}$} & $\begin{array}{l}\text { Narrow } \\
\text { model } \\
(N=216)\end{array}$ & \multirow{2}{*}{$\begin{array}{l}\text { Broad } \\
\text { model } \\
\frac{(N=217)}{P \text {-value }}\end{array}$} \\
\hline & & & $P$-value & \\
\hline G72 & $\mathrm{T}-\mathrm{C}-\mathrm{C}-\mathrm{A}$ & 0.6264 & 0.4834 & 0.5508 \\
\hline rs3916965- & $\mathrm{C}-\mathrm{C}-\mathrm{C}-\mathrm{A}$ & 0.0012 & 0.3312 & 0.3309 \\
\hline rs3916966- & $\mathrm{T}-\mathrm{A}-\mathrm{C}-\mathrm{A}$ & 0.0012 & 0.3171 & 0.3171 \\
\hline rs3916967-rs2391191 & $\mathrm{C}-\mathrm{A}-\mathrm{C}-\mathrm{A}$ & 0.0012 & 0.3176 & 0.3176 \\
\hline (G30 UTR-promoter- & $\mathrm{T}-\mathrm{C}-\mathrm{C}-\mathrm{G}$ & 0.0012 & 0.3188 & 0.3187 \\
\hline promoter-exon 3) & $\mathrm{C}-\mathrm{C}-\mathrm{C}-\mathrm{G}$ & 0.0024 & 0.3453 & 0.3815 \\
\hline & $\mathrm{T}-\mathrm{A}-\mathrm{T}-\mathrm{G}$ & 0.0025 & 0.1601 & 0.1599 \\
\hline & $\mathrm{C}-\mathrm{A}-\mathrm{T}-\mathrm{G}$ & 0.3638 & 0.5099 & 0.5450 \\
\hline G72 & $\mathrm{T}-\mathrm{C}$ & 0.6239 & 0.7836 & 0.7661 \\
\hline rs947 & $\mathrm{G}-\mathrm{C}$ & 0.2335 & 0.7627 & 0.7301 \\
\hline (intron 4-inron 4) & $\mathrm{G}-\mathrm{T}$ & 0.1426 & 0.9701 & 0.9924 \\
\hline
\end{tabular}

$N$ : Number of families. 
German study of DAAO (Schumacher et al., 2004). The DAAO gene is located at the $12 \mathrm{q} 24.11$ locus, and the G72 gene is located at the 13q22-q34 locus. Findings in both of these two chromosomal regions have been inconsistent in demonstrating evidence of linkage to schizophrenia (Bailer et al., 2000; Blouin et al., 1998; Brzustowicz et al., 1999; DeLisi et al., 2002; Fallin et al., 2003; Riley et al., 1998; Shaw et al., 2003). We therefore suggest the inconsistent linkage results should give warning to the SNP fine mapping study for association analyses.

We performed the power estimation of this study using PBAT software (Lange et al., 2004) by assuming there were 218 families with 2 probands without missing parent genotypes. Two inherited models of additive model and multiple model were used by assuming the disease gene frequency as 0.01 and population prevalence as 0.003 . Under 0.05 significant levels, powers for each relative risk of 1.5, 1.8, 2.0 and 2.5 , were $0.1704,0.3619,0.5227$ and 0.8679 , respectively, in additive inherited model. Powers for the same relative risks were $0.172,0.3685,0.5339$ and 0.8221 , respectively, in multiple inherited model. These results indicated that if an allele with a relative risk of over 2.5 , we would have enough power to detect it.

Several explanations for lack of association between G72, DAAO and schizophrenia in this study could be fathomed with the following reasons; i.e. the genetic heterogeneity among ethnic groups. Chumakov et al. (2002) tested SNPs in a French Canadian sample, and Schumacher et al. (2004) used a German population. It is also possible due to the reasons of similar environmental risk factors within these populations having causative alleles for schizophrenia, but not existed in the population of Taiwan. Several studies of G72/DAOA had suggested it as an overlapping gene for bipolar mood disorder and schizophrenia (Craddock and Forty, 2006; Maier et al., 2005; Potash, 2006; Schulze et al., 2005; Williams et al., 2006). The affected individuals in our study were mostly schizophrenia with little mood symptoms and episodes, only two families met the broad definition of phenotype, that is, schizoaffective disorder and other non-affective psychotic disorder. Therefore, the low proportion of schizophrenia associated with mood disorder in our sample set may be less prone to demonstrate association to G72.

In summary, we genotyped three SNPs of DAAO and eleven SNPs of G72 in a relatively large sample of 218 Taiwanese families comprised of 864 subjects, and failed to replicate the association evidence between G72, DAAO and schizophrenia in this family sample.

\section{Acknowledgements}

We acknowledge the SNP genotyping work done by the National Genotyping Center (NGC), and support from the Department of Medical Research, National Taiwan University Hospital. This study was supported by the grants from the National Research Program of Genomic Medicine (NRPGM), National Science Council (NSC), Taiwan (NSC91-2314-B-002-216; NSC913112-B-002-011; NSC 92-3112-B-002-019; NSC933112-B-002-012; NSC94-3112-B-002), the National Health Research Institute, Taiwan (NHRI-EX91,92,93,94-9113PP), Department of Health, Taiwan (DOH94-TD-G-111-035) and the National Institute of Health, U.S.A. (IR01 MH 59624-01).

\section{References}

Abecasis, G.R., Cookson, W.O., 2000. GOLD—graphical overview of linkage disequilibrium. Bioinformatics 16, 182-183.

Bailer, U., Leisch, F., Meszaros, K., Lenzinger, E., Willinger, U., Strobl, R., Gebhardt, C., Gerhard, E., Fuchs, K., Sieghart, W., Kasper, S., Hornik, K., Aschauer, H.N., 2000. Genome scan for susceptibility loci for schizophrenia. Neuropsychobiology 42, 175-182.

Blouin, J.L., Dombroski, B.A., Nath, S.K., Lasseter, V.K., Wolyniec, P.S., Nestadt, G., Thornquist, M., Ullrich, G., McGrath, J., Kasch, L., Lamacz, M., Thomas, M.G., Gehrig, C., Radhakrishna, U., Snyder, S.E., Balk, K.G., Neufeld, K., Swartz, K.L., DeMarchi, N., Papadimitriou, G.N., Dikeos, D.G., Stefanis, C.N., Chakravarti, A., Childs, B., Pulver, A.E., et al., 1998. Schizophrenia susceptibility loci on chromosomes $13 \mathrm{q} 32$ and 8p21. Nat. Genet. 20, 70-73.

Brzustowicz, L.M., Honer, W.G., Chow, E.W., Little, D., Hogan, J., Hodgkinson, K., Bassett, A.S., 1999. Linkage of familial schizophrenia to chromosome 13q32. Am. J. Hum. Genet. 65, 1096-1103.

Chen, W.J., 1999. Diagnostic Interview for Genetic Studies (DIGS) Mandarin Version 2.0. Institute of Epidemiology, College of Public Health, National Taiwan University, Taipei, Taiwan.

Chumakov, I., Blumenfeld, M., Guerassimenko, O., Cavarec, L., Palicio, M., Abderrahim, H., Bougueleret, L., Barry, C., Tanaka, H., La Rosa, P., Puech, A., Tahri, N., Cohen-Akenine, A., Delabrosse, S., Lissarrague, S., Picard, F.P., Maurice, K., Essioux, L., Millasseau, P., Grel, P., Debailleul, V., Simon, A. M., Caterina, D., Dufaure, I., Malekzadeh, K., Belova, M., Luan, J.J., Bouillot, M., Sambucy, J.L., Primas, G., Saumier, M., Boubkiri, N., Martin-Saumier, S., Nasroune, M., Peixoto, H., Delaye, A., Pinchot, V., Bastucci, M., Guillou, S., Chevillon, M., Sainz-Fuertes, R., Meguenni, S., Aurich-Costa, J., Cherif, D., Gimalac, A., Van Duijn, C., Gauvreau, D., Ouellette, G., Fortier, I., Raelson, J., Sherbatich, T., Riazanskaia, N., Rogaev, E., Raeymaekers, P., Aerssens, J., Konings, F., Luyten, W., Macciardi, F., Sham, P.C., Straub, R.E., Weinberger, D.R., Cohen, N., Cohen, D., Ouelette, G., Realson, J., 2002. Genetic and physiological data implicating the new human gene G72 and the gene for D-amino acid oxidase in schizophrenia. Proc. Natl. Acad. Sci. U. S. A. 99, 13675-13680. 
Clayton, D., 1999. A generalization of the transmission/disequilibrium test for uncertain-haplotype transmission. Am. J. Hum. Genet. 65, $1170-1177$.

Craddock, N., Forty, L., 2006. Genetics of affective (mood) disorders. Eur. J. Hum. Genet. 14, 660-668.

DeLisi, L.E., Smith, A.B., Razi, K., Stewart, J., Wang, Z., Sandhu, H. K., Philibert, R.A., 2000. Investigation of a candidate gene for schizophrenia on Xq13 previously associated with mental retardation and hypothyroidism. Am. J. Med. Genet. 96, 398-403.

DeLisi, L.E., Shaw, S.H., Crow, T.J., Shields, G., Smith, A.B., Larach, V.W., Wellman, N., Loftus, J., Nanthakumar, B., Razi, K., Stewart, J., Comazzi, M., Vita, A., Heffner, T., Sherrington, R., 2002. A genome-wide scan for linkage to chromosomal regions in 382 sibling pairs with schizophrenia or schizoaffective disorder. Am. J. Psychiatry 159, 803-812.

Detera-Wadleigh, S.D., McMahon, F.J., in press. G72/G30 in schizophrenia and bipolar disorder: review and meta-analysis. Biol. Psychiatry.

Fallin, M.D., Lasseter, V.K., Wolyniec, P.S., McGrath, J.A., Nestadt, G., Valle, D., Liang, K.Y., Pulver, A.E., 2003. Genomewide linkage scan for schizophrenia susceptibility loci among Ashkenazi Jewish families shows evidence of linkage on chromosome 10q22. Am. J. Hum. Genet. 73, 601-611.

Fukui, K., Miyake, Y., 1992. Molecular cloning and chromosomal localization of a human gene encoding D-amino-acid oxidase. J. Biol. Chem. 267, 18631-18638.

Goldberg, T.E., Straub, R.E., Callicott, J.H., Hariri, A., Mattay, V.S., Bigelow, L., Coppola, R., Egan, M.F., Weinberger, D.R., in press. The G72/G30 gene complex and cognitive abnormalities in schizophrenia. Neuropsychopharmacology.

Horvath, S., Xu, X., Lake, S.L., Silverman, E.K., Weiss, S.T., Laird, N.M., 2004. Family-based tests for associating haplotypes with general phenotype data: application to asthma genetics. Genet. Epidemiol. 26, 61-69.

Hovatta, I., Varilo, T., Suvisaari, J., Terwilliger, J.D., Ollikainen, V., Arajarvi, R., Juvonen, H., Kokko-Sahin, M.L., Vaisanen, L., Mannila, H., Lonnqvist, J., Peltonen, L., 1999. A genomewide screen for schizophrenia genes in an isolated Finnish subpopulation, suggesting multiple susceptibility loci. Am. J. Hum. Genet. $65,1114-1124$.

Hwu, H.G., 1999. Psychiatric Diagnostic Assessment. Manual of Psychiatric Diagnosis, 2nd ed. Publication Committee, College of Medicine, National Taiwan University, Taipei, Taiwan, pp. 7-42.

Hwu, H.G., Chen, C.H., Hwang, T.J., Liu, C.M., Cheng, J.J., Lin, S.K., Liu, S.K., Chi, Y.Y., Ou-Young, C.W., Lin, H.N., Chen, W.J., 2002. Symptom patterns and subgrouping of schizophrenic patients: significance of negative symptoms assessed on admission. Schizophr. Res. 56, 105-119.

Hwu, H.G., Faraone, S.V., Liu, C.M., Chen, W.J., Liu, S.K., Shieh, M.H., Hwang, T.J., Tsuang, M.M., OuYang, W.C., Chen, C.Y., Chen, C.C., Lin, J.J., Chou, F.H., Chueh, C.M., Liu, W.M., Hall, M.H., Tsuang, M.T., 2005. Taiwan schizophrenia linkage study: the field study. Am. J. Med. Genet., Part B Neuropsychiatr. Genet. 134, 30-36.

Korostishevsky, M., Kaganovich, M., Cholostoy, A., Ashkenazi, M., Ratner, Y., Dahary, D., Bernstein, J., Bening-Abu-Shach, U., BenAsher, E., Lancet, D., Ritsner, M., Navon, R., 2004. Is the G72/ G30 locus associated with schizophrenia? Single nucleotide polymorphisms, haplotypes, and gene expression analysis. Biol. Psychiatry 56, 169-176.

Lange, C., DeMeo, D., Silverman, E.K., Weiss, S.T., Laird, N.M., 2004. PBAT: tools for family-based association studies. Am. J. Hum. Genet. 74, 367-369.
Lewontine, R.C., 1964. The interaction of selection and linkage general consideration; heterotic models. Genetics 49, 49-67.

Liu, X., He, G., Wang, X., Chen, Q., Qian, X., Lin, W., Li, D., Gu, N., Feng, G., He, L., 2004. Association of DAAO with schizophrenia in the Chinese population. Neurosci. Lett. 369, 228-233.

Maier, W., Hofgen, B., Zobel, A., Rietschel, M., 2005. Genetic models of schizophrenia and bipolar disorder: overlapping inheritance or discrete genotypes? Eur. Arch. Psychiatry Clin. Neurosci. 255, 159-166.

Mitchell, A.A., Cutler, D.J., Chakravarti, A., 2003. Undetected genotyping errors cause apparent overtransmission of common alleles in the transmission/disequilibrium test. Am. J. Hum. Genet. 72, 598-610.

O'Connell, J.R., Weeks, D.E., 1998. PedCheck: a program for identification of genotype incompatibilities in linkage analysis. Am. J. Hum. Genet. 63, 259-266.

Potash, J.B., 2006. Carving chaos: genetics and the classification of mood and psychotic syndromes. Harv. Rev. Psychiatry 14, 47-63.

Riley, B.P., Lin, M.W., Mogudi-Carter, M., Jenkins, T., Williamson, R., Powell, J.F., Collier, D., Murray, R., 1998. Failure to exclude a possible schizophrenia susceptibility locus on chromosome 13q14.1-q32 in southern African Bantu-speaking families. Psychiatr. Genet. 8, 155-162.

SAS-Institute, 2002. SAS/Genetics User's Guide SAS-Institute.

Schulze, T.G., Ohlraun, S., Czerski, P.M., Schumacher, J., Kassem, L., Deschner, M., Gross, M., Tullius, M., Heidmann, V., Kovalenko, S., Jamra, R.A., Becker, T., Leszczynska-Rodziewicz, A., Hauser, J., Illig, T., Klopp, N., Wellek, S., Cichon, S., Henn, F.A., McMahon, F.J., Maier, W., Propping, P., Nothen, M.M., Rietschel, M., 2005. Genotype-phenotype studies in bipolar disorder showing association between the DAOA/G30 locus and persecutory delusions: a first step toward a molecular genetic classification of psychiatric phenotypes. Am. J. Psychiatry $162,2101-2108$.

Schumacher, J., Jamra, R.A., Freudenberg, J., Becker, T., Ohlraun, S., Otte, A.C., Tullius, M., Kovalenko, S., Bogaert, A.V., Maier, W., Rietschel, M., Propping, P., Nothen, M.M., Cichon, S., 2004. Examination of G72 and D-amino-acid oxidase as genetic risk factors for schizophrenia and bipolar affective disorder. Mol. Psychiatry 9, 203-207.

Shaw, S.H., Mroczkowski-Parker, Z., Shekhtman, T., Alexander, M., Remick, R.A., Sadovnick, A.D., McElroy, S.L., Keck Jr., P.E., Kelsoe, J.R., 2003. Linkage of a bipolar disorder susceptibility locus to human chromosome 13q32 in a new pedigree series. Mol. Psychiatry 8, 558-564.

Sobel, E., Lange, K., 1996. Descent graphs in pedigree analysis: applications to haplotyping, location scores, and marker-sharing statistics. Am. J. Hum. Genet. 58, 1323-1337.

Wang, X., He, G., Gu, N., Yang, J., Tang, J., Chen, Q., Liu, X., Shen, Y., Qian, X., Lin, W., Duan, Y., Feng, G., He, L., 2004. Association of $\mathrm{G} 72 / \mathrm{G} 30$ with schizophrenia in the Chinese population. Biochem. Biophys. Res. Commun. 319, 1281-1286.

Williams, N.M., Green, E.K., Macgregor, S., Dwyer, S., Norton, N., Williams, H., Raybould, R., Grozeva, D., Hamshere, M., Zammit, S., Jones, L., Cardno, A., Kirov, G., Jones, I., O’Donovan, M.C., Owen, M.J., Craddock, N., 2006. Variation at the DAOA/G30 locus influences susceptibility to major mood episodes but not psychosis in schizophrenia and bipolar disorder. Arch. Gen. Psychiatry 63, 366-373.

Zhang, S.L., Kidd, K.K., Zhao, H.Y., 2002. Detecting genetic association in case-control studies using similarity-based association tests. Stat. Sin. 12, 337-359. 